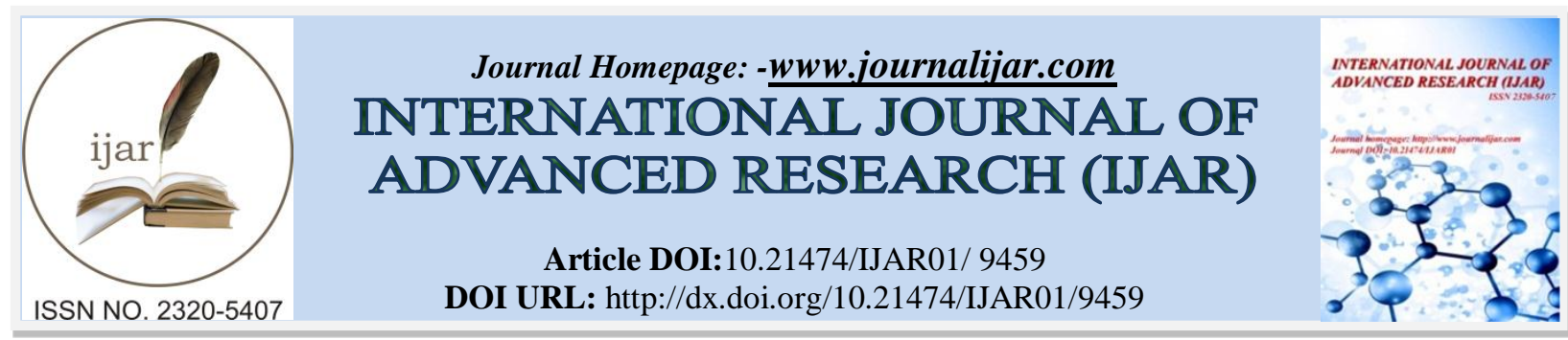

RESEARCH ARTICLE

\title{
THE SOCIAL ECONOMIC IMPACT OF THE COMMUNITY AROUND LANDFILL THROUGH EDUCATION TOURISM MANAGEMENT AT SUMOMPO LANDFILL, MANADO.
}

\author{
Debby ch rende $^{1}$, Z. Fanani ${ }^{2}$, H. riniwati ${ }^{2}$ and B. yanuwiadi ${ }^{2}$.
}

1. Postgraduate student of brawijaya university.

2. Postgraduate lecturer of brawijaya university.

\section{Manuscript Info}

\section{Manuscript History}

Received: 26 May 2019

Final Accepted: 28 June 2019

Published: July 2019

Key words:-

Social economic, Landfill, Tourism Management

\begin{abstract}
This study aimed to determine the impact that arises from the community around Landfill in realizing educational tourism in the Sumpompo Landfill in Manado City. The method used in this study was descriptive methods through survey methods. The results of this study indicated that the majority of respondents still have low education, 41 percent only graduating from elementary school which affected the respondents' type of work where 60 percent of respondents worked in the non-formal sector with irregular work such as drivers, scavengers and housewives. Nevertheless the respondent's response to the existence of educational tours at Landfill is quite good. To respond to the low level of education of respondents around the Landfill area, a good socialization of the surrounding community is needed, besides providing appropriate training and supporting activities around the site will help improve the socio-economic conditions of the community throughout the Landfill.
\end{abstract}

Copy Right, IJAR, 2019,. All rights reserved.

\section{Introduction:-}

One of the main problems faced by Indonesia is how to handle the increasing amount of household waste in urban areas, lack of resources and infrastructure, the implementation of the $3 \mathrm{R}$ program is not yet optimal. Another problem is that environmental policies are not suitable and there are still many stakeholders and policy makers in cities that do not care about hazardous waste in their efforts to increase economic growth (Ahemka, 2015)

Another problem with waste is in handling waste management, especially in an effort to reduce the volume of waste and process it into forms that have value and benefits (Zubair and Haeruddin, 2012). As an initial step, participation from all parties is needed to improve waste management services and sustainability of environmental policies. Therefore, the public relations strategy needs to be adapted to specific targets and offer opportunities for real action. Consultation activities and training on sustainable waste management with targeted communities or should be a priority in order to support initiative relations. This needs to be accompanied by financing, such as actions or activities through competitive external projects that are much larger in capital and human resources. The importance of community involvement in waste management greatly determines the success of environmentally conscious projects in waste management (Zatos et al., 2009).

Corresponding Author:-Debby Ch Rende.

Address:-Postgraduate Student of Brawijaya University. 
Creating an attractive educational tour requires creativity that can change a place that initially has no value, becomes a tourist destination that has a high selling value. Educational tourism aims to make Landfill as a place for visiting tourists who are made with the aim of obtaining learning from these tourist attractions. The concept used in educational tourism is non-formal education for tourists or visitors to tourist attractions. This has been implemented by the Landfill manager of Sumompo Village, Manado, by utilizing land used as a Landfill protector against environmental pollution due to waste processing activities such as buffer zones, capable of being used for tourism activities. buffer, able to be used for tourism activities.

As mention as Douglas Pearce (1989), there are at least six main components in the tourism development plan that need to be considered. The First Component according to Pearce is the spatial inventory pattern (space) including the availability of the main elements and supporting elements of tourism such as: tourist attractions, transportation, accommodation, supporting facilities and other services, and the availability of adequate infrastructure. The second is the pattern of spatial demand, which related to the habits and desires of tourists in tourism activities. Third, the geographical conditions of tourism objects, which include; geological, topographic conditions, soil stability, climate, season and physical conditions of the tourism object in question. Fourth, the flow and movement of tourists, this includes potential tourist destinations, length of stay, tourism costs, accessibility between regions. Fifth, the impact of tourism, namely increasing the standard of living of local communities through multiplier effect activities, decreasing environmental and perceptual carrying capacity, and sixth, concerning models of potential tourism development.

Seeing from the potential in the Sumompo Landfill in Manado City, in general it has requirements that can support the making of the Sumompo Landfill in Manado as one of the garbage education tours that has a fairly good selling value. This can have a positive impact on the community around the Landfill in Sumompo, Manado City and will also serve as a model for other Landfills to be able to develop and become waste as objects that have economic value and also make the area an educational tourism destination. The purpose of this study was to look at the socioeconomic conditions of the people around the Sumompo Landfill to become Landfill education.

\section{Research Purpose:-}

Based on the formulation of the problem above, the objectives of this study are as follows:

Analyzing the impact that arises from the community around Landfill in realizing educational tourism in the Sumpompo Landfill in Manado City

\section{Research Methods:-}

This research was carried out in a quantitative descriptive manner using survey methods as a way of systematically gathering information on respondents with the intention of understanding and or predicting some observed aspects of respondents (Rangkuti, 2007). Survey methods pay more attention to sampling, questionnaire design, administration of questionnaires and data analysis. To obtain the data needed in this study, the author uses several data collection methods as follows:

1. Questionnaire, a method of collecting data by circulating a structured list of questions addressed to the community as actors of waste management Interview, namely the method carried out by conducting interviews or question and answer directly to the community and related policy makers (SKPD) involved in the process waste management.

2. Observation, the method of data collection carried out by direct observation of the treatment of waste management by the community and related waste management services (SKPD).

3. Literature Study, the process of collecting data carried out by using scientific references or references that are relevant to the object of research as secondary data.

\section{Research Result And Discussion:-}

The issue of waste in the city of Manado is still an important problem, the production of garbage that continues to increase, with the limited capacity of the Sumompo Landfill is a new problem that must be found in school roads. One of the influences is the composition of waste disposed in Sumompo Landfill; the composition of waste is generally expressed in the form of weight or volume and organic or inorganic waste. 
Based on the results of field surveys obtained and recorded from the administration at Sumompo Landfill the results of several types of specifications for the garbage selection category carried out include:

1. Organic waste: food waste, plants, leftover garbage from vegetables and fruits and other fragile waste.

2. Plastic waste: plastic bottles, plastic bags, packaging, HDPE, PP and other types that are not biodegradable

3. Paper Waste: newspapers, HVS paper, cardboard or cardboard, tetra pack and food wrappers

4. Rubber / leather rubbish: rubber and synthetic leather

5. Textile Waste: clothing, patchwork and fabric

6. Others: electronic, medical, glass, diapers, sand etc.

The easiest source of waste to destroy is organic waste, which is mostly produced by households and markets.

Based on observational studies found that the initial conditions of the Sumompo Landfill in waste management still use the open dumping method. This system still uses the method of dumping the waste left unchecked and after full it will be disposed of elsewhere. The traditional management still made restlessness for the surrounding community, resulting in a plan to make the Sumompo Landfill an educational tourism area.

Respondents who were sampled in this study were dominated by men as much as 61 percent and women by 38 percent, where most of the respondents are productive age population (31-50 years) as much as 41 percent. The work of respondents of 66 percent is scavenger, driver and housewife as in Figure 1.

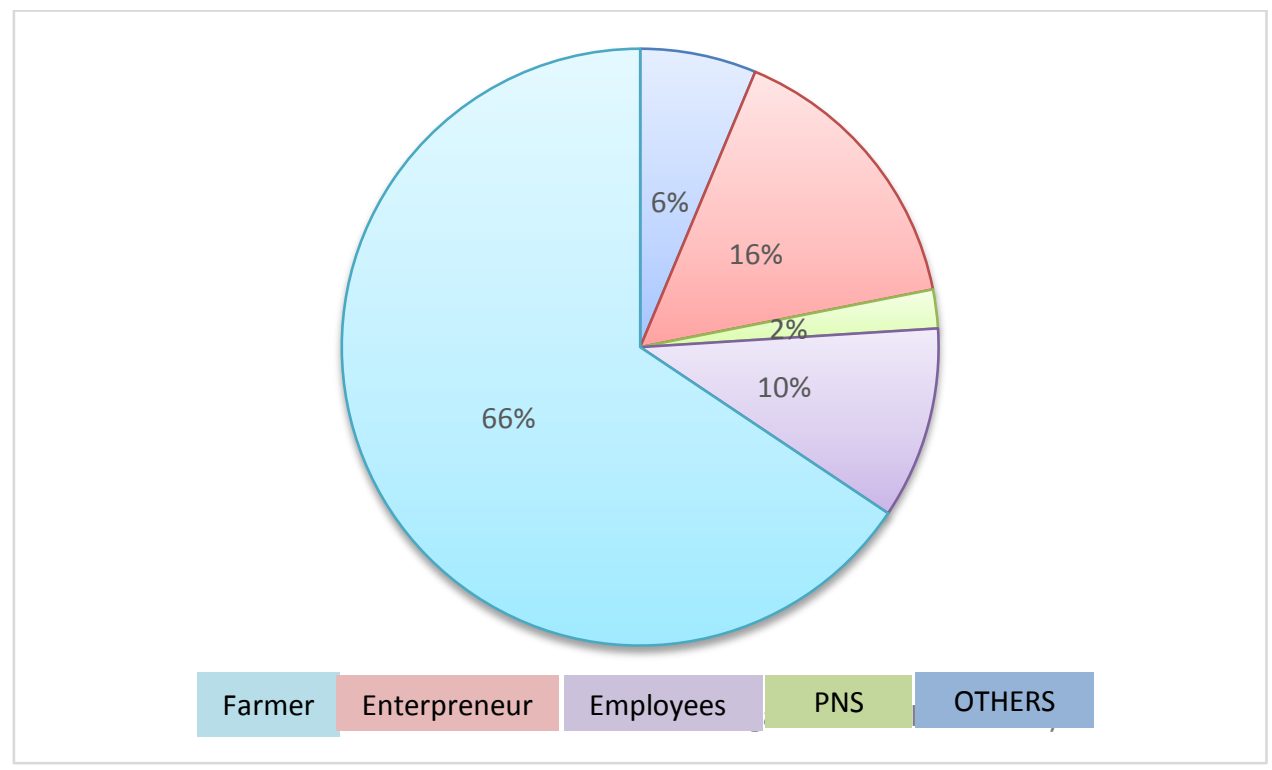

Figure 1:-Respondents' Job Types

Source: data processed, 2019

According to this data, respondents who worked as farmers / breeders were 6 percent, entrepreneurs were 16 percent and civil servants were 2 percent. There are still many respondents who work irregularly or odd jobs related to the education level of the respondents. The level of education is still said to be low, namely only 25 percent of respondents who graduated from high school and equivalent. The high number of respondents who only finished elementary school was 42.7 people.

Before the construction of the Sumompo Landfill, the community had been given education; this made the condition of the community not to be surprised and objected to the existence of the landfill. Discourse makes Sumompo Landfill an educational tour that responds well to the surrounding community. Various environmental, social problems that are thought to be obstacles can be overcome very well. This is because a successful environmental conservation-based Landfill management system is implemented around the Landfill area. The benefits that exist are not only felt by the Landfill managers themselves but also the surrounding community. Landfill educational tourism is one of the alternatives for community tourism destinations today that have educational themes, especially environmental conservation education. With the development of technology and information at this time, 
Talangagung education tourism Landfill began to be known to the wider community and even became a pilot Landfill for several regions in Indonesia. The existing tourism potential is very well developed and utilized by landfill managers so that many tourists visit to enjoy the tourist attractions offered. This situation certainly has a positive impact on the surrounding community, especially from the economic aspect of the community.

The results of the interview indicated that the lack of socialization carried out by the government in the management of landfill made the community less aware of the purpose and objectives of developing educational tourism in the Sumompo Landfill area. Nevertheless the respondents showed a positive response to the management of Landfill but the respondents still felt afraid and worried about the impacts that would arise from the Landfill.

The socialization of the benefits and safety of environmental-friendly Landfill management needs to be done in depth and intensively to the community. This is important because when people feel insecure with the existence of Landfill, the sustainability of the Landfill program will be threatened in the future. According to Malik et.al. (2015), communities will have an awareness of environmental conservation-based waste management practices when they know and understand the impact of this. Therefore, the role of local governments to improve people's understanding is very important.

The Malang Regency regional government program that established Sumompo Landfill as an educational tourist destination received support from respondents. More than $90 \%$ of respondents agreed on each question point asked to describe their attitude towards the policy. Hoie, M., et al., 2010., and Stone, TH, et al., 2010., states that attitudes are a tendency to respond positively and negatively to an object through persuasion, role models from someone or from a social group.

The existence of the Sumompo Landfill, currently, provides benefits not only for Landfill managers but also for surrounding communities. Benefits that can be felt by the community are not only from the environmental aspect but also from the economy. One proof of this benefit is that the Landfill management has built a methane gas channel system, as a result of waste management activities, which is integrated into the homes of surrounding residents. This methane gas can be used by the community for daily activities such as cooking. Thus, local people can save on expenses per day. Besides that, in Sumompo Landfill there are also various supporting facilities that can be utilized by every visitor who comes.

\section{Conclusions And Recommendations:- Conclusions:-}

The waste management system at Sumompo Landfill has changed from an open dumping system to a controlled Landfill based on environmental conservation insights. The availability and normal functioning of basic, operational, supporting and environmental protection facilities are the main tools in waste management activities at landfill every day. Planning of waste management activities in the Landfill has been prepared and is always carried out as planned. Overall, good management of the Sumompo Landfill has been well responded to by the management of the Talangagung Landfill, which has been adapted to the national policy on waste management and developed into an education tourism Landfill in the Malang area. The waste management system in Talangagung Landfill can be used as a learning and tourism facility for people around the Landfill and visitors of various ages. Learning in this Landfill is focused on efforts to increase people's understanding of the conservation of the surrounding environment. In general, the behavior of respondents covering the community and landfill managers supports the planned landfill tourism education program. The respondent's knowledge, actions, perceptions, and attitudes towards the presence of Talangagung Landfill are in line with the policies set by the local government or the landfill manager with regard to the management of environmental conservation-based Landfill education.

\section{Suggestion :-}

To support the creation of educational tours in the Sumompo Landfill, it is necessary to carry out actions including the ongoing socialization of the surrounding community. Socio-economically, the low level of education will affect people's ability to adjust to the changes that occur. Providing training in accordance with the conditions of the characteristics of the community around the landfill will help the community's ability to improve and improve the socio-economic conditions of the community.

The behavior of the community around the landfill that supports well-supported educational tourism programs requires active and participatory community involvement with the use of various facilities and outputs through 
coaching with the establishment of healthy and independent institutions so that the community around the landfill has a sense of Landfill ownership.

\section{Bibliography:-}

1. Amheka, A.; Higano, Y.; Mizunoya, T.; Yabar, H. 2015. An Overview of Current Household Waste Management in Indonesia: Development of A New Integrated Strategy. Int. J. Environment and Waste Management, Vol. 15. No. 1. pp. 86-98.

2. Anwar, A. 2003. Konflik Sampah Kota. Komunitas Jurnal Bekasi.

3. Anonimous. 2015. Kajian Kebijakan dan Strategi Nasional Percepatan Pengelolaan Sampah : Laporan Akhir. Kementerian Koordinator Bidang Perekonomian Republik Indonesia, Deputi Bidang Koordinasi Percepatan Infrastruktur dan Pengembangan Wilayah, Asisten Deputi Telematika dan Utilitas.

4. Bujagunasri, Y. 2009. Estimasi Manfaat dan Kerugian Masyarakat Akibat Keberadaan Tempat Pembuangan Akhir : Studi Kasus di TPA Bantar Gebang, Kota Bekasi. Skripsi. Institut Pertanian Bogor.

5. Damanhuri, E. and Padmi, T. 2009. Current Situation of Waste Recycling in Indonesia, in Kojima, M. and E. Damanhuri (eds.), 3R Policies for Southeast and East Asia. ERIA Research Project Report 2008-6-1. Pp. 23-52. Jakarta: ERIA.

6. Djuwendah, Endah dkk.(2000). "Analisis Keragaan Ekonomi dan Kelembagaan Penanganan Sampah Perkotaan” di Kotamadya Bandung, Jawa Barat: Laporan Penelitian, Lembaga Penelitian UNPAD.

7. Hadiwiyoto, S. 1983. Penanganan dan Pemanfaatan Sampah. Yayasan Idahu. Jakarta.

8. Guerrero, L. A.; Maas, G.; Hogland, W. 2013. Solid Waste Management Challenges for cities in Developing Country. Journal Waste Management Vol. 33(1). pp. 220-232.

9. Ismeidi; Angreni, E.; Titah, H. S. 2013. Evaluasi Sistem Pembuangan Akhir Sampah di TPA Ngadirojo Kota Wonogiri. ISBN No. 978-979-18342-0-9. pp. 19-32.

10. Hendrawan, I. D. 1996. Dampak Lokasi Pembuangan Akhir (LPA) Sampah Sanitary Landfill Terhadap Pencemaran Lingkungan (Studi Kasus di Bantar Gebang Bekasi). Tesis. Sekolah Pascasarjana. Institut Pertanian Bogor. Bogor.

11. Hornweg, D. and Bhada-Tata, P. 2012. What a Waste : A Global Review of Solid Waste Management. Urban Development Series. The World Bank.

12. Mavropoulos, A. 2013. Waste Management 2030+. Waste Management World Magazine. PenWell Corporation. Oklahoma, US.

13. Meidiana, C. and Gamse, T. 2010. Development of Waste Management Practices in Indonesia. European Journal of Scientific Research. Vol. 40. No. 2. pp. 199-210.

14. Rangkuti, F. A. 2014. Dampak Keberadaan Tempat Pembuangan Akhir Sampah (TPAS) "Namo Bintang" Terhadap Masyarakat (Studi Kasus: Desa Namo Bintang, Kecamatan Pancur Batu, Kabupaten Deli Serdang). Skripsi. Institut Pertanian Bogor.

15. Sankoh, F. P.; Yan, X.; Tran, Q. 2013. Environmental and Health Impact of Solid Waste Disposal in Developing Cities : A Case Study of Granville Brook Dumpsite, Freetown, Sierra Leona. Journal of Environmental Protection, 4. pp. 665-670.

16. Sembel, A. T. 2015. Toksikologi Lingkungan. Penerbit Andi. Yogyakarta.

17. Suhatono, Dicky; Kanto, Sanggar dan Mu'adi, Sholih. 2014. Kajian Tentang Makna, Penyebab dan Strategi Penanggulangan Kemiskinan (Kajian Fenomenologi Komunitas Pemulung di TPA Supit Urang Kota Malang). Jurnal Wacana Vil 17, No. 4

18. Su, M. I.; Warouw, V. R. Ch.; Karamoy, L. T. 2017. Analisis Kualitas Air di Sekitar Situs TPA Sumompo Kota Manado. Ejournal.unsrat. Vol. 1 No. 5.

19. Techobanoglous, G. 1977. Integrated Solid Waste Management Engineering Principles and Management Issue. Mc. Graw Hill. Inc. New York.

20. Vidanaarachchi, C. K.; Yuen, S. T. S.; Pilapitiya, S. 2006. Municipal Solid Waste Management in the Southern Province of Srilanka : Problems, Issues and Challenges. J. Waste Management, 26. pp. 920-930.

21. Yahaya, O.; Umoh, V.; Ameh, J. B. 2013. Public Health Implications of Using Water from Wells Located Near Municipal Waste Dump Sites in parts of Zaria. Journal of Enviromental and Waste Management Vol. 1(5), pp. 96-100.

22. Zotos, G.; Karagiannidis, A.; Zampetoglou, S.; Malamakis, A.; Antonopoulos, I. S.; Kontagianni, S.; Tchobanoglous, G. Developing a Holistic Strategy for Integrated Waste Management Within Municipal Planning : Challenges, Policies, Solutions and Perspectives for Hellenic Municipalities in the Zero-Waste, LowCost Direction. J. Waste Management, 29. pp. 1686-1692. 